\title{
The Impact of Employee Empowerment In Organizational Performance With Special Reference To IT Sector
}

\author{
Gunita Arun Chandhok, Saranya.J
}

\begin{abstract}
In view of the rapidly changing business environment, the success of an organization depends on committed, highly motivated, satisfied and innovative human resources. Employee empowerment is gaining momentum in the effective functioning of an enterprise. This paper focuseson the role and importance of employee empowerment with reference to organizational, occupational and individual factors supported by employee motivation based on Maslow's theory, in the Information technology sector.
\end{abstract}

Key words: Employee, empowerment, motivation,organization.

\section{INTRODUCTION}

The IT industry has made the world a worldwide village, reduced domestic borders and integrated cultures.India has been able to accelerate its development through this sector.Different scientists have looked at the aspects of empowerment through varying angels. Controlling one's own work, work autonomy, teamwork differences, and pay-performance structures all refer to empowerment.Maslow created his theory of hierarchy in which food is our basic necessity; in pyramidal, we move up to the greatest self-realization requirements.Each phase of human development is based on a previous phase and every phase is moved to a greater sequence.Every employee in an organization should be recognized as an individual, since what motivates one individual cannot motivate another.Circles of quality have been superseded by employee empowerment; motivation schemes operate only if the staff are confident that leadership is ready to make real efforts.

Employee Empowerment is the method by which a person can believe, act, regulate and take decisions in independent ways or authorize them to take decisions.It is a state of self-empowerment in which you take control of your own fate.Empowerment is not what one is doing for another in human relationships.This is one of the issues with the notion of empowerment in organizations.People believe that someone, generally the manager, should empower the individuals who tell him.The reporting employees, therefore, wait for the empowerment, and the manager asks why individuals are not empowered.This resulted in a general, largely undeserved lack of joy in many organizations with the notion of empowerment.The organization is responsible for

Revised Version Manuscript Received on August 19, 2019.

Dr. Gunita Arun Chandhok, Director, Guru Nanak College, Chennai, Tamilnadu, India.(Email: gunitachandhok@yahoo.com)

Saranya.J, Assistant Professor, Guru Nanak College, Chennai, Tamilnadu, India.(Email: saranya.kart@gmail.com) creating a working atmosphere that promotes employees capacity and willingness to behave empowered.The Workplace is responsible for removing obstacles which restrict the capacity of employees to behave with empowerment.

\section{OBJECTIVES OF THE STUDY}

- To examine the relationship between empowerment and employee motivation

- To analyze the motivational factors of employees with Maslow's Need theory

- To identify and study the factors of empowerment which positively influence employee motivational need theory in the IT sector

\section{REVIEW OF LITERATURE}

Uman and Vasanathi (1999) argued that there is now widespread acceptance of the practical significance of Maslow's theory. Physiological needs are taken into account in decision-making regarding space, lighting and general working conditions; work safety; love for cohesive work teams; appreciation through responsibility and recognition ; self-actualisation in terms of providing opportunities for creative jobs or tasks.

According to Chandler (2004), the most widely-known theory of motivation was the one developed by Abraham Maslow in his book entitled Theory of Human Motivation typically referred to as the hierarchy of needs. A hierarchy of five fundamental levels was built by Maslow.In addition to these requirements, there are greater needs. These include the need for knowledge, recognition and purely spiritual requirements.In the five basic Maslow-related requirements, a person will not feel the second need, until the requests of the first or the third have been met.Nearly all continuous employees have significantly met their lower-order requirements. The hierarchical theory is often portrayed as a pyramid, while the bigger, smaller theory represents the smaller requirements and the highest theory is the self-actuality.

Jhul and Wilkinson (1997) explained the objective of the empowerment process is to improve employee power, understanding, motivation for the job ; thus, to improve employees ' contribution to business satisfaction and customer satisfaction, while at the same moment increasing 
respect for themselves, trust and allegiance towards the business.

As per Honold, (1997) suggested The empowerment content can be explained: since it can be achieved at an individual level, it can be achieved at a team level that includes all staff in size in one process, in one unit, in a business or in one organization.

Yazdani, B.O, (2011) explains Empowerment offers organizations advantages and makes sense of workforce membership and pride.It establishes a win-win relationship between companies and staff and is seen by many companies and their staff as an optimal setting. The empowerment of virtual human abilities can thrive.

\section{CONCEPTUAL FRAMEWORK FOR THE STUDY}

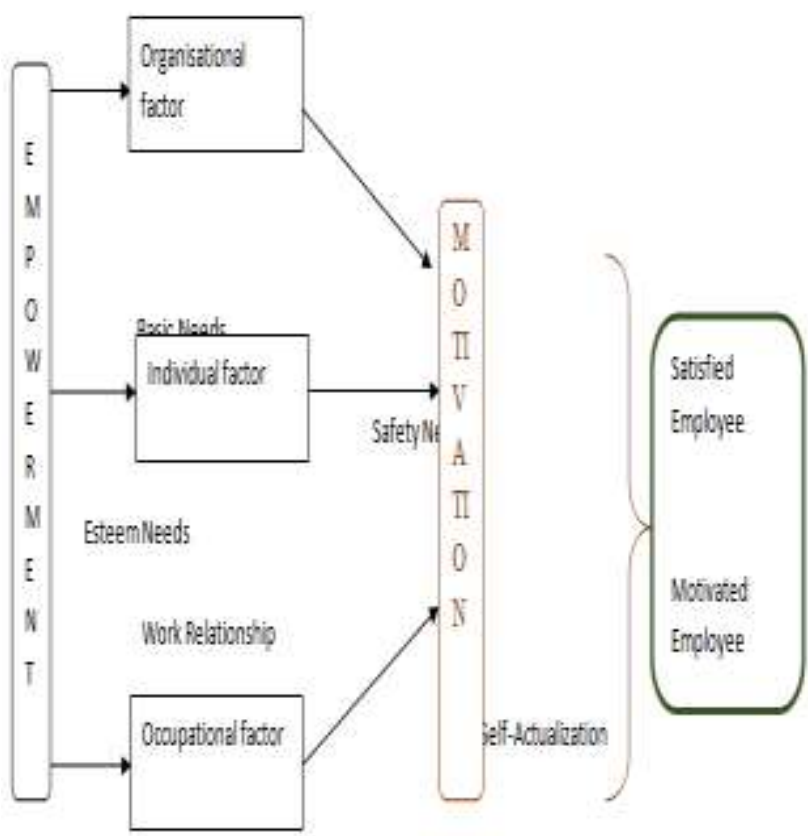

Fig: 1 Conceptual Framework for the present study

In order to be effective in the dynamic business environment of today, organizations have to be able to foster the wish of employees to participate and produce, that is, have to be able to influence and motivate their workforce, act, achieve the desired objectives. They need to combine the various human capacities and powers of many people employed in a smooth working team with high levels of human resources. Unfortunately, a process isn't so easy to empower and motivate. The mixture of individual requirements, drivers, tensions, discomfort, and expectations is complicated. Every person's motive is currently ' partially understood, ' and even the easiest.Moreover, needs vary significantly with the individual and lead to differential behavior patterns. The other matter even further, an individual's needs vary over time, his value system evolves continually, and an integral part of that evolution is the motivational process. As some needs are satisfied, they become less important in the scheme of things. Others develop through experience.

According to the conceptual model for the present study states that though there are different forms of empowerment present, but for the present study the three forms of empowerment the organizational, individual and occupational factors are studied to find out whether they influence the motivation aspect in view of Maslow's motivational need theory which includes the basic, safety, esteem, affection for work relationship and self-actualization need of an individual person. This paper focuses on how the empowerment factors are influencing and empowering the different motivation factors and the outcomes aresatisfied and motivated employees.

\subsection{Empowerment}

Empowerment is one of the many ideas in HRM.Empowerment is what young employees in organizations' are looking for.In addition to monetary rewards, the worker has the impression that he or she is nowadays motivated by the work. Empowerment can be considered to be "a method to improve the self-efficiency of organizational employees by identifying circumstances that promote impotence, and by removing them through both official organizational procedures and casual methods of data delivery."Strong and enthusiastic staff are empowered.It is because they receive personal rewards for this that they are seeking a better job.The employee's emotions of empowerment are the answer to employee performance. The model described in this figure assumes that there are much distinct significance, interpretations, and expectations of empowerment, but since leadership policies are taken and implemented to satisfy the organizational and business purposes, an understanding of the significance and myths that executives use in terms of empowerment must be developed.

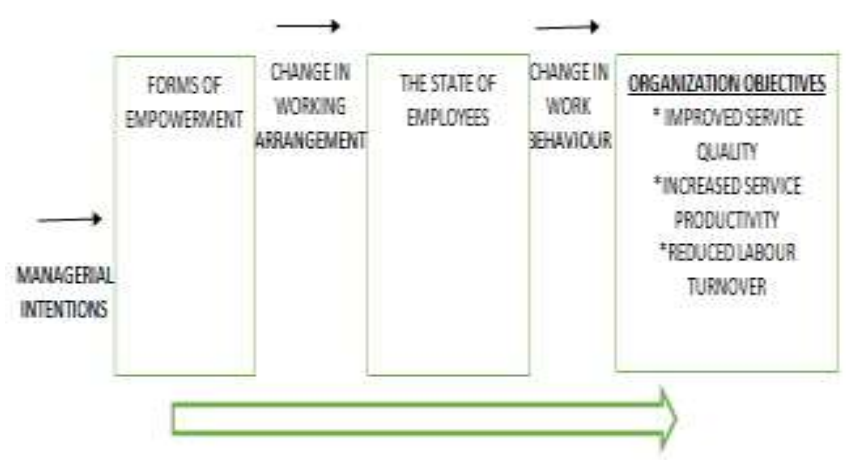

Fig: 2key stages in empowerment

\section{RESEARCH METHODOLOGY}

The research is to find the employee empowerment in the organization and to study the relationship between employee empowerment and motivation.

Research Design:

Descriptive researchhas been used as a research design.

\section{Sampling techniques:}

Simple Random sampling has been used.

Data Collection:

Data is collected through Questionnaire. Primary Data was collected using a Questionnaire. 
Sample Size:

Among the total level of population, 50 employees from the IT sector have been chosen for the study.

Tools and Techniques:

- Paired t-test analysis

- Correlation analysis

- Friedman test analysis

\section{DATA ANALYSIS AND INTERPRETATION \& RESULTS}

\subsection{Paired T Test Analysis}

Paired T-test analysis is used to compare between two factors of Need theory and will compare which factor among them is favored by the employees.

\section{Null hypothesis:}

There is no significant difference between the mean score of factor Esteem and factor Self Actualization.

\section{Alternative hypothesis:}

There is a significant difference between the mean score of factor Esteem and factor Self Actualization.

Table : 1 Paired T Test

\begin{tabular}{|l|l|l|l|l|}
\hline Factors & $\begin{array}{l}\text { Mea } \\
\mathbf{n}\end{array}$ & $\begin{array}{l}\text { Std. } \\
\text { Deviati } \\
\text { on }\end{array}$ & $\begin{array}{l}\text { t } \\
\text { Valu } \\
\text { e }\end{array}$ & $\begin{array}{l}\text { P } \\
\text { Value }\end{array}$ \\
\hline Esteem & $\begin{array}{l}12.4 \\
5\end{array}$ & 3.62 & 1.41 & $\begin{array}{l}0.001 * \\
*\end{array}$ \\
\cline { 1 - 3 } $\begin{array}{l}\text { Self-Actualizat } \\
\text { ion }\end{array}$ & $\begin{array}{l}12.5 \\
5\end{array}$ & 3.65 & 4 & \\
\hline
\end{tabular}

NOTE: ** Denotes the significant level at $1 \%$

\section{Inference:}

Since P-value is less than 0.01 then the null hypothesis is rejected at $1 \%$ level of significance. Hence, it is concluded that there is a significant difference between the mean score of esteem and self-actualization.Based on mean score the opinion regarding self-actualization $\{12.55\}$ is better than the esteemed factor $\{12.45\}$.

\subsection{Correlation Analysis}

Correlation analysis is used in this study to find whether the empowerment and the motivation are having a perfect correlation.

\section{Null hypothesis:}

There is no relationship between the empowerment and motivation in this study.

\section{Alternative hypothesis:}

There is a relationship between empowerment and motivation in this study.
Table: 2correlations Analysis

\begin{tabular}{|c|c|c|c|}
\hline \multicolumn{4}{|c|}{ Correhtions } \\
\hline & & Motiration & Empowement \\
\hline \multirow[t]{3}{*}{ Motivation } & Pearson Conclation & 1 & $.65^{*}$ \\
\hline & Sigg. (2tailed) & & .000 \\
\hline & N & 50 & 50 \\
\hline \multirow[t]{3}{*}{ Emporrement } & Pearson Conelation & $.615^{* 1}$ & 1 \\
\hline & $\operatorname{Sig}$ (2+2aled) & .000 & \\
\hline & N & 50 & 50 \\
\hline
\end{tabular}

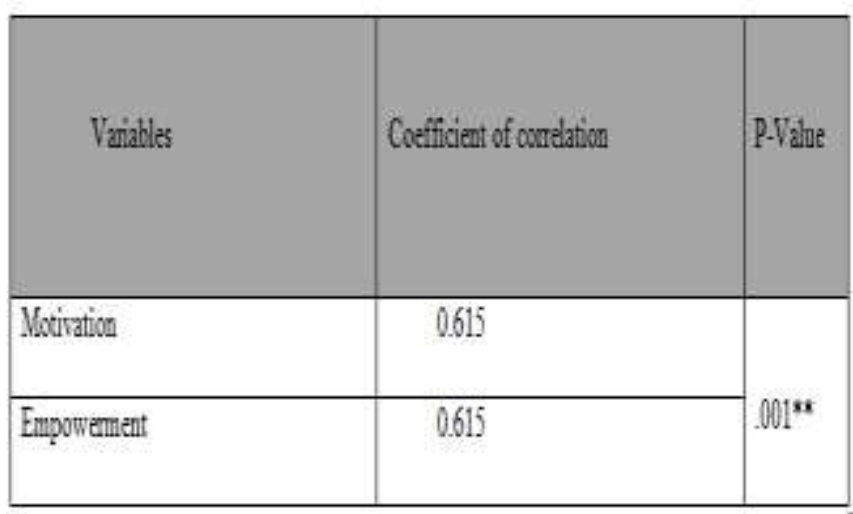

NOTE: ** Denotes the significant level at $1 \%$

\section{Inference:}

Since P-Value is less than 0.001 , hence the null hypothesis is rejected at $1 \%$ level of significant. The correlation and coefficient between motivation and empowerment are 0.615 which indicates $61.5 \%(0.615 / 50)$ positive relation between empowerment and motivation. Many authors suggest that empowerment is one of the major driving forces of motivation which further enhances Performance and productivity and helps to retain employees.

\subsection{Friedman Test Analysis}

This test is used to find whether a significant difference between the ranks among the motivation factors i.e. between basic need, safety, esteem, work relationship, and self-actualization.

\section{Null hypothesis:}

There is no significant difference between the mean ranks towards factor on motivation factor.

\section{Alternative hypothesis:}

There is a significant difference between the mean ranks towards factor on motivation factor. 
Table: 3 Friedman Analysis For Motivational Factor

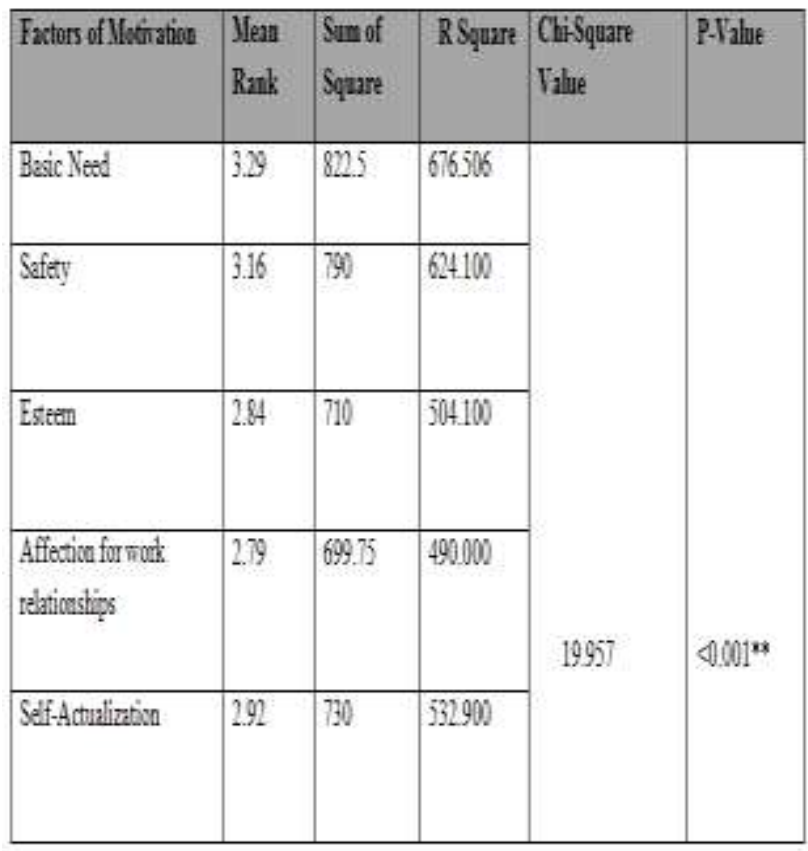

\section{Inference:}

Since P-value is less than 0.001 the null hypothesis is rejected at $1 \%$ level of significant difference between mean ranks towards factors on motivation. Based on mean rank basic need (3.29) is an important factor on motivation, followed by safety (3.16), esteem (2.84), affection for work relationship (2.79), and self-actualization (2.92).

\subsection{Friedman Test Analysis}

\section{Null hypothesis:}

There is no significant difference between the mean ranks among the empowerment factor.

\section{Alternative hypothesis:}

There is a significant difference between the mean ranks among the empowerment factor.

Table: 4 Friedman Test Analyses For Empowerment Factor

\begin{tabular}{|c|c|c|c|c|c|}
\hline $\begin{array}{l}\text { Factors of } \\
\text { Empower } \\
\text { ment }\end{array}$ & $\begin{array}{l}\text { Mea } \\
\text { n } \\
\text { Ran } \\
\mathbf{k}\end{array}$ & $\begin{array}{l}\text { Sum } \\
\text { of } \\
\text { Squa } \\
\text { re }\end{array}$ & $\begin{array}{c}\text { R } \\
\text { Square }\end{array}$ & $\begin{array}{l}\text { Chi-Squ } \\
\text { are } \\
\text { Value }\end{array}$ & $\begin{array}{l}\text { P-Val } \\
\text { ue }\end{array}$ \\
\hline $\begin{array}{l}\text { Organisatio } \\
\text { nal Factor }\end{array}$ & 2.81 & 702.5 & $\begin{array}{l}493506 . \\
25\end{array}$ & \multirow{4}{*}{31.96} & \multirow{4}{*}{0.001} \\
\hline $\begin{array}{l}\text { Occupation } \\
\text { al Factor }\end{array}$ & 1.96 & 490 & 240100 & & \\
\hline $\begin{array}{l}\text { Individual } \\
\text { Factor }\end{array}$ & 1.23 & 307.5 & $\begin{array}{l}94556.2 \\
5\end{array}$ & & \\
\hline & & & & & \\
\hline
\end{tabular}

Inference:
Since P-value is less than 0.001 the null hypothesis is rejected at $1 \%$ level of significant difference between mean ranks towards factors on motivation. Based on the mean rank Organisational factor (2.81) is an important factor in empowering the employees, followed by an occupational factor (1.96), individual factor (1.23).

\section{SUGGESTIONS}

Following suggestions will be helpful to motivate and empower the employee of the organization.

1. It shows as the work experience is increasing the level of an organisational factor in empowerment is also decreasing. Employees working for more than 5 years show less interest in the organisational factor. Organizations should adopt new ways to motivate and empower the employees to retain them and to motivate them. The employee's role in the current position should be enhanced.

2. Proper career planning should be made for the employees working for more than 5 years so that employees feel the growth in the job and remain in the same organization and be a motivated workforce.

3. The employees working for a long time in the organisation should be provided with further education schemes and trainingprograms so that employee feels growth and bright future with working experience and can improve skills. Employees working for more than 8 years should be provided appraisals, job position, and financial growth.

4. The employees opted for self-actualization among the esteem and self-actualization factor of motivation. To improve the esteemed factor for employees, organizations should provide them with responsibility for the job completion and role in the organization, should give the accountability for work done, should be provided with the status i.e. position in the organization and visibility and transparency with the management.

\section{LIMITATIONS OF THE STUDY}

The research study is limited to a few aspects. The study has considered only limited variables while assessing motivation and empowerment, and its different determinants and the measuring approach of respondents is quite subjective. Although great care was taken for precision, yet there may be certain gaps which need to be rectified. The model needs to be tested on a larger dataset. Many employees were not interested in giving a response, perhaps many felt that the domain of factors like motivation and empowerment of their workforce (or perhaps lack of it) was a sensitive area and believed that it would reflect poorly on the organization. However, if more variables are taken into consideration, and if the questions used to measure the respondents' attitudes toward work are re-evaluated and adjusted, a better result can be attained.

1. The study is based on the sample size of 50 employees from IT sector organizations only.

2. The study is restricted to units located in Chennai city only hence has geographical limitations.

3 . The subject of motivation and empowerment is 
extensive and vast. Therefore, investigating all aspects of it was not possible due to the time limit and the enormous research that already existed.

\section{CONCLUSION}

The world is currently experiencing fast environmental transformations, which have a drastic effect on organizations and present fresh difficulties to the overall leadership of human resources and motivation. The present study tries to look at motivation beyond the limited frontiers of business and economics by also studying the strong motivation practices amongst and how the factor empowerment is affecting the IT sector. The research tends to come up with such a motivation model to be implicated in the IT sector so as to yield much higher productivity through a highly empowered and motivated workforce. The study clearly shows that there is a positive association between motivation and empowerment in IT sectors. It demonstrates that a satisfied employee will demonstrate greater commitment to the organization.

\section{REFERENCES}

1. Adair. J.(1996), Effective Motivation: How to get Extraordinary results from everyone. (1st ed.). New Delhi: Rupa \& Co.

2. Ajila, C. O. (1997), Maslow's hierarchy of needs theory: Applicability to the Nigerian industrial setting. IFE Psychology: An International Journal, 5, 162-174, http://etd.fcla.edu/CF/CFE0003816/Kennedy_Robert_C_ 201108_PhD.pdf.

3. Aswathappa, Human Resource, and Personnel Management, Tata McGraw-Hill Education, 2005 - Human Resources

4. 4. Bruce. A, Pepiton. J. (1999), Motivating Employee. United States: McGraw - Hill International.

5. Christensen, L.B., (1988),Experimental Methodology. (4thed): Allyn \& Bacon Publishers.

6. Fulford, Mark D. \&Enz, Cathy A,"The Impact of Empowerment on Service Employees",Academic journal article from Journal of Managerial Issues, Vol. 7, No. 2

7. Greenberg. J, Baron.R, Behavior in Organizations. Understanding and Managing the Human Side of Work. (5th Ed.). New Delhi: Prentice Hall of India Pvt Ltd.

8. Gupta. N, Gupta. A. (1998), Essentials of management.Principles, practices \& techniques. New Delhi: Anmol publications Pvt. Ltd.

9. Gupta. S, Gupta. M. (1990),Business Statistics. (9th Ed.).New Delhi: Sultan Chand \& Sons.

10. Jyothi B.S \& Dr. P.T. Ravindran, "Employee Job Satisfaction in Software and ITeS units in Bangalore -An Empirical study", Business Management Dynamics Vol.2, No.6, Dec 2012, pp.46-55 